\title{
Dependence of the Selection of Thymineless Mutants on the Acriflavine Sensitivity in Escherichia coli Treated with Aminopterin
}

\author{
By H. NAKAMURA \\ Biological Institute, Faculty of Science, Konan University, \\ Kobe, Japan
}

(Accepted for publication 22 July 1971)

INTRODUCTION

Thymineless $\left(t h y^{-}\right)$mutants are obtained at a high frequency when bacteria are grown in the presence of aminopterin (APT), a folic acid antagonist (Okada, Yanagisawa \& Ryan, I960). On the other hand, the acriflavine (AF) sensitivity of Escherichia coli $\mathrm{K}-\mathrm{I} 2$ is determined by a gene acr $A$ located near lac (Nakamura, 1965, 1968). This report shows that the frequency of $t h y^{-}$mutants in $E$. coli treated with APT is dependent upon the allelism of the acr $A$ gene.

\section{METHODS}

Bacterial strains. Strain N43 is an acrA (AF sensitive) mutant of Escherichia coli K-I2. Strain $\mathrm{N} 90$ is an $a c r A^{+}$(AF-resistant) recombinant from a cross W I $895 \mathrm{Hfr} \mathrm{acr}^{+} \times \mathrm{N}_{43} \mathrm{~F}^{-}$ acr $A$ interrupted at $4 \mathrm{~min}$. Thus, most of the chromosome of $\mathrm{N} 90$ is common to that of $\mathrm{N} 43$.

Media. Broth PGY contained (per 1.): polypeptone (Daigo-eiyo), 5 g.; yeast extract (Daigo-eiyo), I g.; NaCl, 3 g.; glucose, I g. Initial pH of the medium was adjusted to $7 \cdot 4$ with I N-NaOH. When yeast extract was omitted it is referred to as PG. Minimal medium $\mathbf{S}$ corresponds to $S_{1}$-glucose of Nakamura (1965). In some cases, $S$ was enriched with $0.25 \%(\mathrm{w} / \mathrm{v})$ Casamino acids and $20 \mu \mathrm{g} . / \mathrm{ml}$. of tryptophane.

Isolation of AF-resistant mutants of $\mathrm{N} 43$. Method $\mathrm{I}$ : Since $\mathrm{N} 43$ is also sensitive to phenethyl alcohol, phenethyl alcohol-resistant mutants were isolated by the method of Nakamura (1968). These mutants were also resistant to AF. Method 2: AF-r mutants were directly selected on PGY agar containing AF (I00 $\mu \mathrm{g} . / \mathrm{ml}$.).

Determination of the frequency of thy- mutants after APT treatment. S medium-grown cells were inoculated to $\mathrm{S}$ medium containing $500 \mu \mathrm{g} . / \mathrm{ml}$. APT with an inoculum size about $10^{6} \mathrm{cells} / \mathrm{ml}$. and after $24 \mathrm{~h}$. shaking, $200 \mu \mathrm{g}$. $/ \mathrm{ml}$. of thymidine was added to allow growth of $t h y^{-}$cells. From inoculation to full turbidity of the cultures required $\mathrm{I} / \mathrm{h}$. for $\mathrm{N} 43$ and $52 \mathrm{~h}$. for N90. The final cultures were streaked on PG agar supplemented with Io $\mu \mathrm{g} . / \mathrm{ml}$. thymidine and clones were isolated. Thymine requirement of the clones was confirmed on solid and liquid S media with and without thymidine enrichment (Io $\mu \mathrm{g}$. $/ \mathrm{ml}$.).

\section{RESULTS}

Frequency of thy $y^{-}$mutants. Table I shows the frequency of the thy- mutants in the AF-s strain N43 and the AF-r strain N90 treated with APT. The N43 cultures were much richer in mutants than the N90 cultures. When small colonies were selectively picked from the APT-treated N90 PG plate, the frequency of thy- mutants was somewhat higher than when 
large colonies were picked. With $\mathrm{N} 43$, on the other hand, no such relationship between colony size and frequency of thy $y^{-}$mutants was obtained.

When small and large colonies from the APT-treated N90 plates were picked and subcultured separately in PGY medium, colony size was not clonal. No significant difference in AF sensitivity between clones of the two types of colonies was detected when they were tested by the gradient plate method (Nakamura, 1965). Thus, the colony size effect on the yield of thy $y^{-}$mutants may be due to a partial shortage of exogenous thymidine.

Table I. Frequency of thymineless mutants in strains $\mathrm{N} 43, A F-s$ and $\mathrm{N} 90, A F-r$, treated with $A P T^{*}$

$\begin{array}{cccc}\text { Strain } & \begin{array}{c}\text { Expt. } \\ \text { no. }\end{array} & \begin{array}{c}\text { No. of } \\ \text { clones } \\ \text { tested }\end{array} & \begin{array}{c}\text { Frequency }(\%) \\ \text { of } t h y \\ \text { mutants }\end{array} \\ & \text { I } & 200 & 60 \cdot 5 \\ & 2 & 100 & 98 \cdot 0 \\ & 3 & 90 & 74 \cdot 4 \\ & 4 & 100 & 93 \cdot 0 \\ & 5 & 100 & 71 \cdot 0 \\ & 6 \dagger & 100 & 100 \\ & 7 \ddagger & 100 & 98 \cdot 0 \\ & 1 & 200 & 0 \cdot 5 \\ & 2 & 168 & 0 \\ & 3 \dagger & 100 & 5 \cdot 0 \\ & 4 \dagger & 100 & 8 \cdot 0 \\ & 5 \dagger & 200 & 8 \cdot 0 \\ & 6 \dagger & 100 & 8 \cdot 0 \\ & 7 \dagger & 100 & 0 \\ & 8 \dagger & 100 & 0 \\ & 9 \dagger & 100 & 0\end{array}$

* Cultures treated with aminopterin $(500 \mu \mathrm{g} . / \mathrm{ml}$.) were then supplemented with thymidine $(200 \mu \mathrm{g} . / \mathrm{ml}$.) and spread on PG agar medium supplemented with thymidine (10 $\mu \mathrm{g} . / \mathrm{ml}$.). After overnight incubation colonies were tested for thymine requirement.

$\dagger$ and $\ddagger$ Small and large colonies, respectively, were selectively picked and tested for thymine requirement.

Mutants of $\mathrm{N} 43$ having variable levels of AF resistance were obtained by seeding $\mathrm{N} 43$ on a gradient plate containing $\mathrm{AF}(100 \mu \mathrm{g}$. $/ \mathrm{ml}$.) in the upper layer and picking colonies which appeared along the AF concentration gradient. Clones of these mutants were subjected to the APT treatment and the yield of thy- mutants was determined. The frequency of thy mutants correlated positively with the level of AF sensitivity. Therefore, there is little doubt that the yield of $t h y^{-}$mutants after APT treatment is affected by the acr $A$ gene.

Cross-sensitivity between $A F$ and $A P T$. Overnight cultures of strains N43 and N9o were inoculated into Casamino acids-enriched $\mathrm{S}$ medium containing 40,100 , and $200 \mu \mathrm{g}$. $/ \mathrm{ml}$. APT and shaken at $37^{\circ}$. At intervals samples were plated on PGY agar to count viable organisms. With N43, growth was remarkably inhibited (about $50 \%$ of control rate) by $100 \mu \mathrm{g} . / \mathrm{ml}$. and thymineless death occurred after one generation in $200 \mu \mathrm{g} . / \mathrm{ml}$. APT. With $\mathrm{N} 90$, on the other hand, growth was not inhibited by $100 \mu \mathrm{g} . / \mathrm{ml}$. at all and only slightly inhibited (about $85 \%$ of control rate) by $200 \mu \mathrm{g}$./ml. APT.

Three revertants of $\mathrm{N} 43$ selected for resistance to phenethyl alcohol and one, N 562 (Nakamura, I968), selected for resistance to AF were tested for sensitivity to APT. All the revertants were more resistant to APT than their parents. Therefore, it is concluded that gene acr $A$ determines sensitivity to APT. 


\section{DISCUSSION}

In $a c r A^{-}$cultures $t h y^{-}$mutants possess much more selective advantage in the presence of APT than thy mutants in $a c r A^{+}$cultures. This is because growth of the acr $A^{-}$strain is inhibited more strongly by APT than that of the $a c r A^{+}$strain and thy mutants are resistant to APT, which therefore acts as a selective agent, not as a mutagen (Okada et al. 1960).

APT binds strongly to the enzyme dihydrofolate reductase and inhibits production of tetrahydrofolate and eventually, thymidylate (Jukes \& Broquist, I963). Several explanations have been proposed to account for alterations of APT sensitivity in bacteria. A change in dihydrofolate reductase that increases its activity or makes the enzyme less sensitive to APT (Sirotnak, Donati \& Hutchison, I964a, b; Albrecht, Palmer \& Hutchison, 1966); formation of a metabolic bypass which is insensitive to APT (Wilson, Farmer \& Rothman, 1966); a mutational loss of thymidylate synthetase activity (Bertino \& Stacey, I966); a change in permeability to APT. It is known that the uptake of folate and APT are essentially nil in Escherichia coli and some other organisms. However, strains can be selected which show an increased uptake of APT and folate and thus sensitivity to APT (Wood \& Hitchings, I959; Pine, 1960; Hitchings \& Burchall, I965). APT transport is assumed to be due to a permease specific for folate. On the other hand a general increase in permeability to various substances cannot be ruled out.

Studies on the AF sensitivity have demonstrated that $\operatorname{acr} A^{-}$is a membrane mutation causing increased permeability to basic dyes and thus increased sensitivity to dyes and to lipophilic substances (Nakamura, 1965, I966, 1967a, $b$, I968). Thus acr $A^{-}$cells are more permeable to APT than wild-type cells and APT selects more strongly against thy $y^{+}$acr $A^{-}$ than against $t h y^{+} a c r A^{+}$and favours the growth of $t h y^{-}$acr $A^{-}$mutants which are resistant to APT.

Stacey \& Simon (1965) found that selection of thy- mutant was much easier if trimethoprim, a dihydrofolate reductase inhibitor, was used and suggested that this is because Escherichia coli are permeable to the drug. (This is another example in E. coli that the efficiency of a drug for the selection of thy- mutants depends on the cellular permeability.)

I wish to thank Dr Joji Ashida, Ehime University, and Dr Sohei Kondo, Osaka University, for discussion and advice on the manuscript, and Miss Hiroko Fukui for excellent technical assistance.

\section{REFERENCES}

Albrecht, A. M., Palmer, J. L. \& Hutchison, D. J. (i966). Differentiating properties of the dihydrofolate reductase of amethopterin-resistant Streptococcus faecalis/AK and the sensitive parent strain. Journal of Biological Chemistry, 24r, 1043-1048.

Bertino, J. B. \& Stacey, K. A. (1966). A suggested mechanism for the selective procedure for isolating thymine-requiring mutants of Escherichia coli. Biochemical Journal ror, $32 \mathrm{C}$.

Hitchings, G. H. \& Burchall, J. J. (1965). Inhibition of folate biosynthesis and function as a basis for chemotherapy. Advances of Enzymology 27, 4I 7-468.

Jukes, T. H. \& Broquist, H. P. (I963). In Metabolic inhibitors, vol. I, p. 48I. Edited by R. M. Hochster \& J. H. Quastel. New York: Academic Press.

NaKAmura, H. (1965). Gene-controlled resistance to acriflavine and other basic dyes in Escherichia coli. Journal of Bacteriology 90, 8-14.

NAKAMURA, H. (1966). Acriflavine-binding capacity to Escherichia coli in relation to acriflavine sensitivity and metabolic activity. Journal of Bacteriology 92, I447-I452.

NAKAMURA, H. (1967a). Changes in sensitivity to acriflavine of Escherichia coli grown in media of different glucose contents. Journal of General Microbiology 49, 443-449. 
Nakamura, H. (1967b). Phenethyl alcohol sensitivity in Escherichia coli. Journal of Bacteriology 93, I183I 84 .

NAKAmURA, H. (1968). Genetic determination of resistance to acriflavine, phenethyl alcohol and sodium dodecylsulfate in Escherichia coli. Journal of Bacteriology 96, 987-996.

OKadA, T., YANAGISAWA, K. \& RYAN, F. J. (I960). Elective production of thymineless mutants. Nature, London I88, 340-34I.

Pine, M. J. (1960). Uptake of aminopterin by Bacillus subtilis. Journal of Bacteriology 79, 827-834.

SirotnaK, F. M., Donati, G. J. \& Hutchison, D. J. (1964a). Dihydrofolate reductase in genotypically distinguishable amethopterin-resistant Diplococcus pneumoniae. Journal of Biological Chemistry 239, 2677-2682.

Sirotnak, F. M., Donati, G. J. \& Hutchison, D. J. (I964b). Genetic modification of the structure and amount of dihydrofolate reductase in amethopterin-resistant Diplococcus pneumoniae. Journal of Biological Chemistry 239, 4298-4302.

StaceY, K. A. \& Simon, E. (1965). Improved method for the isolation of thymine-requiring mutants of Escherichia coli. Journal of Bacteriology 90, 554-555.

Wilson, M. C., FARMER, J. L. \& Rothman, F. (1966). Thymidylate synthesis and aminopterin resistance in Bacillus subtilis. Journal of Bacteriology 92, $186-196$.

Wood, R. C. \& Hitchings, G. H. (1959). A study of the uptake and degradation of folic acid, citrovorum factor, aminopterin, and pyrimethamine by bacteria. Journal of Biological Chemistry 234, 238I-2385. 